\section{Sectorial evolutions in former communist economies, current EU members}

Cătălina MOTOFEI PhD., Bucharest University of Economic Studies,

E-mail: cmotofei@yahoo.com

\section{Alostract}

In this paper, the author assumes the analysis of the economic sectors that contribute to the formation of Gross Value Added for eight selected countries, former communist economies, which are members of the European Union. The study outlines the impact of each factor across the analyzed interval and then, through multiple regression, a panel of independent variables is selected from the basic set of ten, classified on NACE Rev. 2, and the impact of those variables on the main indicator, Gross Value Added, is measured.

Keywords: contribution, factor, industry, regression, gross value added

JEL Classification: C51, E01

\section{To cite this article:}

Motofei, C. (2017), Sectorial evolutions in former communist economies, current EU members, Audit Financiar, vol. XV, no. 2(146)/2017, pp. 266-275,

DOI: 10.20869/AUDITF/2017/146/266

To link to this article:

http://dx.doi.org/10.20869/AUDITF/2017/146/266

Received: 15.01.2017

Revised: 20.03.2017

Accepted: 21.03.2017 


\section{Introduction}

The Gross Value Added (GVA) is one of the main components of the Gross Domestic Product (GDP), according to the production method. The GVA contributes to the formation of GDP together with the net taxation. Net taxation is taxation less subsidies related to the production measured through the GVA. According to Eurostat, GVA "is defined as output value at basic prices less intermediate consumption valued at purchasers' price" (http://ec.europa.eu/eurostat/web/productsdatasets/-/teina404_r2). The Eurostat methodology details the value of this indicator by ten components, in compliance with NACE Rev. 2.

Our analysis followed two methods: first, we have pursued the contribution of each factor to the formation of the main indicator and then, by applying the multiple regression method, we have measured the impact of four factors.

In the last section of the paper, we have realized an econometric analysis of the influence exerted by the four most important factors on the GDP of the respective countries.

\section{Literature review}

The book authored by Anghelache, Mitruț and Voineagu (2013) includes a comprehensive presentation of the indicators related to macroeconomic results. Astafieva (2014) discusses on the factors that influence the value added in industry. Bălănescu (2013) evaluates the position of the SMEs in the context of the Romanian economy. lachimov (2013) analyzes the characteristics of data and information sources for regional level studies. Piroi and Păunică (2015) evaluate the impact of technology on the deficit of the Romanian budget. Lehmann and Wohlrabe (2013) study the forecast of GVA per sectors, at regional level. Melihovs and Kasjanovs (2011) develop on the evolution of convergence process in Latvia. Motofei (2017) has analyzed a group of factors that contribute to the structure and evolution of GDP for several countries. Pawlas (2015) presents some characteristics on the Visegrad Countries and European Union membership. Stoykova-Kanalieva (2010) evaluates, from a comparative viewpoint, the Romanian and Bulgarian economies. Păunică et al.
(2009) develop on performance in the public administration sector.

\section{Research methodology and data}

The research methodology is based on the resources that contribute to the formation of the GVA, whose influence is subsequently applied to the evolution of GDP. The classification of the indicators is based on NACE rev 2. According to the Eurostat, NACE represents "the statistical classification of economic activities in the European Community" (http://ec.europa.eu/eurostat/documents/3859598/59025 21/KS-RA-07-015-EN.PDF), being "subject of legislation at the European Union level, which imposes the use of the classification uniformly within all the Member States" (http://ec.europa.eu/eurostat/documents/3859598/59025 21/KS-RA-07-015-EN.PDF). Thus, the groups of indicators taken into consideration, as influence factors, are the following:

- Agriculture, forestry and fishing;

- Industry (except construction);

- Construction;

- Wholesale and retail trade, transport, accommodation and food service activities;

- Information and communication;

- Financial and insurance activities;

- Real estate activities;

- Professional, scientific and technical activities; administrative and support service activities;

- Public administration, defense, education, human health and social work activities;

- Arts, entertainment and recreation; other service activities; activities of household and extra-territorial organizations and bodies.

The data were extracted from the Eurostat online database and processed through a data analysis software.

\section{Resullis and discussions}

The datasets for each country are presented in a separate chart. We have calculated and discussed also on the aggregated values, corresponding to the entire period in Table no. 1. 


\section{Table no. 1. The contribution by categories of resources to the formation of the GVA}

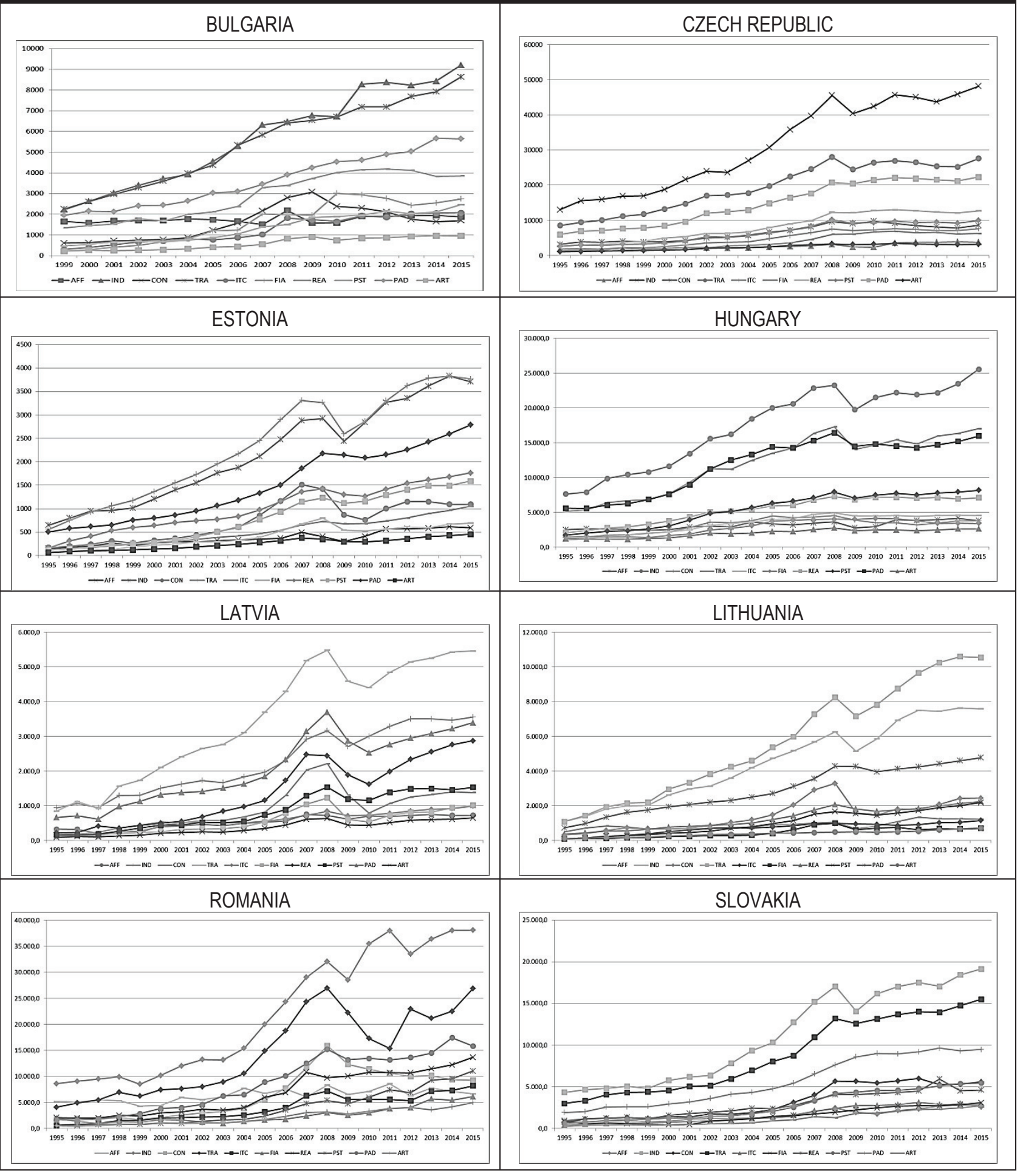

Data source: Eurostat, graphical representation by the author

Dataset: National Accounts aggregates by industry (up to NACE A*64) [nama_10_a64], extracted March 16th, 2017 
The Bulgarian economy is influenced in a major proportion by the industry and the trade outcomes. These two indicators, for the total amounts of the analyzed interval, hold a total share of more than $43 \%$. The least significant factor is the Arts, entertainment and recreation etc., with a weight slightly above $2 \%$.

Regarding the situation of the Czech economy, there can be observed the significant contribution of industry, close to a third (in terms of aggregated amount, $31.09 \%$ ) for the $1995-2015$ period. The second position in the hierarchy corresponds to trade activity, while the Arts, entertainment and recreation etc. is placed on the last position (2.37\%).

Estonian dataset reveals a somehow different pattern, with a high contribution of the trade related activities (23.12\% for the total period), followed closely by the industrial sector $(21.56 \%)$, and the last position is held by the Arts, entertainment and recreation etc.

For the Hungarian economy, the industry holds the first position (26.99\%), with the trade activities $(17.97 \%)$ on the second place within the hierarchy. We note the weight of the factor Public administration, defense, education, human health and social work activities, which is almost equal to the trade $(17.70 \%)$. As in the case of the other analyzed economies, the smallest contribution is associated with the Arts, entertainment and recreation; other service activities; activities of household and extra-territorial organizations and bodies, that is little over $3 \%$.

In Latvia, the most prominent factor, from the viewpoint of our analysis methodology is the trade, accounting for almost $27 \%$ for the entire interval considered. The second place is held by the Industry (except construction) activity, with $17.40 \%$, and the Public administration, defense, education, human health and social work activities is the third in the top. The least sizable influence corresponds to Arts, entertainment and recreation; other service activities; activities of household and extra-territorial organizations and bodies, below 3\%.

The Lithuanian economy is highly influenced by the factor Wholesale and retail trade, transport, accommodation and food service activities, that is the same situation with the other Baltic former soviet countries. The contribution of this sector amounts, for the entire period, to $29.35 \%$. Following, on the second and third position, are the Industry (except construction) and Public administration, defense, education, human health and social work activities, with $23.31 \%$ and $15.13 \%$ respectively. As in the case of other economies, the sector Arts, entertainment and recreation; other service activities; activities of household and extra-territorial organizations and bodies, has the smallest contribution, little above $2 \%$.

In Romania, the most visible contribution belongs to Industry (except construction), with $28.50 \%$, with the trade and public administration related activities taking the second and third positions, respectively. In Slovakia, we can observe the significant weights for Industry (except construction), and Wholesale and retail trade, transport, accommodation and food service activities, who amount for almost half of the GVA for the entire analyzed interval. The weakest influence is associated with Arts, entertainment and recreation; other service activities; activities of household and extra-territorial organizations and bodies, whose weight is less than $3 \%$.

Then, we have analyzed the contribution of the first four factors to the evolution of the GVA, by using multiple regression. The data source was kept the same, and the variables were defined, for softwareassisted processing purposes, as the following set:

- Agriculture, forestry and fishing (AFF);

- Industry (except construction) (IND);

- Construction (CON01);

- Wholesale and retail trade, transport, accommodation and food service activities (TRA).

The multiple regression model is constructed on the basis of the following equation:

$\mathrm{GVA}=\mathrm{a}_{0}+\mathrm{a}_{1} \cdot \mathrm{AFF}+\mathrm{a}_{2} \cdot \operatorname{IND}+\mathrm{a}_{3} \cdot \mathrm{CON01}+\mathrm{a}_{4} \cdot \mathrm{TRA}$

The regression models were estimated on the basis of the least squares method. The results are presented in the Table no. 2. 


\section{Table no. 2. Estimation of regression equation - individual country case}

\section{BULGARIA}

Dependent Variable: GVA

Method: Least Squares (Gauss-Newton / Marquardt steps)

Date: 03/17/17 Time: 13:28

Sample (adjusted): 19992015

Included observations: 17 after adjustments

$\mathrm{GVA}=\mathrm{C}(1)+\mathrm{C}(2)^{\star} \mathrm{AFF}+\mathrm{C}(3)^{\star} \mathrm{IND}+\mathrm{C}(4)^{*} \mathrm{CON} 01+\mathrm{C}(5)^{\star} \mathrm{TRA}$

\begin{tabular}{crrrr}
\hline \hline & Coefficient & Std. Error & t-Statistic & Prob. \\
\hline \hline C(1) & -879.8759 & 2313.851 & -0.380265 & 0.7104 \\
C(2) & 0.880221 & 1.444290 & 0.609449 & 0.5536 \\
C(3) & 2.394875 & 0.746146 & 3.209658 & 0.0075 \\
C(5) & 1.629295 & 0.425833 & 3.826138 & 0.0024 \\
& 1.629665 & 0.870254 & 1.872632 & 0.0857 \\
\hline \hline R-squared & 0.994462 & Mean dependent var & 25870.24 \\
Adjusted R-squared & 0.992616 & S.D. dependent var & 9973.835 \\
S.E. of regression & 857.0789 & Akaike info criterion & 16.58487 \\
Sum squared resid & 8815010. & Schwarz criterion & 16.82993 \\
Log likelihood & -135.9714 & Hannan-Quinn criter. & 16.60923 \\
F-statistic & 538.6800 & Durbin-Watson stat & 1.234870 \\
Prob(F-statistic) & 0.000000 & & & \\
\hline \hline
\end{tabular}

\section{ESTONIA}

Dependent Variable: GVA

Method: Least Squares (Gauss-Newton / Marquardt steps)

Date: 03/23/17 Time: 18:53

Sample: 19952015

Included observations: 21

$\mathrm{GVA}=\mathrm{C}(1)+\mathrm{C}(2)^{*} \mathrm{AFF}+\mathrm{C}(3)^{*} \mid \mathrm{ND}+\mathrm{C}(4)^{*} \mathrm{CON} 01+\mathrm{C}(5)^{*} \mathrm{TRA}$

\begin{tabular}{crrrr}
\hline \hline & Coefficient & Std. Error & t-Statistic & Prob. \\
\hline \hline C(1) & 52.37488 & 202.0525 & 0.259214 & 0.7988 \\
$\mathrm{C}(2)$ & -4.014868 & 1.701812 & -2.359172 & 0.0314 \\
$\mathrm{C}(3)$ & 4.198683 & 0.627660 & 6.689421 & 0.0000 \\
$\mathrm{C}(4)$ & 1.376138 & 0.543975 & 2.529782 & 0.0223 \\
$\mathrm{C}(5)$ & 0.588484 & 0.713924 & 0.824295 & 0.4219 \\
\hline \hline R-squared & 0.997364 & Mean dependent var & 10077.06 \\
Adjusted R-squared & 0.996705 & S.D. dependent var & 5035.951 \\
S.E. of regression & 289.0588 & Akaike info criterion & 14.37539 \\
Sum squared resid & 1336880. & Schwarz criterion & 14.62409 \\
Log likelihood & -145.9416 & Hannan-Quinn criter. & 14.42937 \\
F-statistic & 1513.612 & Durbin-Watson stat & 1.487661 \\
Prob(F-statistic) & 0.000000 & & & \\
\hline \hline
\end{tabular}

\section{LATVIA}

Dependent Variable: GVA

Method: Least Squares (Gauss-Newton / Marquardt steps)

Date: 03/23/17 Time: 19:00

Sample: 19952015

Included observations: 21

$\mathrm{GVA}=\mathrm{C}(1)+\mathrm{C}(2)^{\star} \mathrm{AFF}+\mathrm{C}(3)^{\star} \mathrm{IND}+\mathrm{C}(4)^{\star} \mathrm{CON} 01+\mathrm{C}(5)^{\star} \mathrm{TRA}$

\begin{tabular}{crrrr}
\hline & Coefficient & Std. Error & t-Statistic & Prob. \\
\hline \hline C(1) & -1042.611 & 251.6676 & -4.142810 & 0.0008 \\
C(2) & -0.707085 & 1.493049 & -0.473585 & 0.6422 \\
C(3) & 3.109730 & 0.320150 & 9.713349 & 0.0000 \\
C(4) & 2.745873 & 0.273693 & 10.03267 & 0.0000 \\
C(5) & 1.394366 & 0.254565 & 5.477440 & 0.0001 \\
\hline \hline R-squared & 0.998646 & Mean dependent var & 12942.84 \\
Adjusted R-squared & 0.998307 & S.D. dependent var & 6518.854 \\
S.E. of regression & 268.2124 & Akaike info criterion & 14.22569 \\
Sum squared resid & 1151006. & Schwarz criterion & 14.47439 \\
Log likelihood & -144.3698 & Hannan-Quinn criter. & 14.27967 \\
F-statistic & 2949.621 & Durbin-Watson stat & 0.821209 \\
Prob(F-statistic) & 0.000000 & & & \\
\hline \hline
\end{tabular}

\section{CZECH REPUBLIC}

Dependent Variable: GVA

Method: Least Squares (Gauss-Newton / Marquardt steps)

Date: $03 / 23 / 17$ Time: 18:49

Sample: 19952015

Included observations: 21

$\mathrm{GVA}=\mathrm{C}(1)+\mathrm{C}(2)^{\star} \mathrm{AFF}+\mathrm{C}(3)^{\star} \mathrm{IND}+\mathrm{C}(4)^{\star} \mathrm{CON} 01+\mathrm{C}(5)^{\star} \mathrm{TRA}$

\begin{tabular}{crlll}
\hline \hline & Coefficient & Std. Error & t-Statistic & Prob. \\
\hline \hline C(1) & -13852.08 & 4289.556 & -3.229256 & 0.0052 \\
$\mathrm{C}(2)$ & 5.595142 & 2.453157 & 2.280793 & 0.0366 \\
$\mathrm{C}(3)$ & 1.146196 & 0.477770 & 2.399055 & 0.0290 \\
$\mathrm{C}(4)$ & 5.023415 & 1.350020 & 3.720993 & 0.0019 \\
$\mathrm{C}(5)$ & 1.628523 & 0.467813 & 3.481141 & 0.0031 \\
\hline \hline R-squared & 0.998592 & Mean dependent var & 100497.1 \\
Adjusted R-squared & 0.998241 & S.D. dependent var & 40222.27 \\
S.E. of regression & 1687.155 & Akaike info criterion & 17.90373 \\
Sum squared resid & 45543867 & Schwarz criterion & 18.15243 \\
Log likelihood & -182.9892 & Hannan-Quinn criter. & 17.95770 \\
F-statistic & 2837.798 & Durbin-Watson stat & 1.467636 \\
Prob(F-statistic) & 0.000000 & & & \\
\hline \hline
\end{tabular}

HUNGARY

Dependent Variable: GVA

Method: Least Squares (Gauss-Newton / Marquardt steps)

Date: 03/23/17 Time: 18:58

Sample: 19952015

Included observations: 21

$\mathrm{GVA}=\mathrm{C}(1)+\mathrm{C}(2)^{\star} \mathrm{AFF}+\mathrm{C}(3)^{\star} \mathrm{IND}+\mathrm{C}(4)^{\star} \mathrm{CON} 01+\mathrm{C}(5)^{\star} \mathrm{TRA}$

\begin{tabular}{crrrr}
\hline \hline & Coefficient & Std. Error & t-Statistic & Prob. \\
\hline \hline C(1) & 1946.039 & 2551.261 & 0.762775 & 0.4567 \\
C(2) & -0.694939 & 1.180666 & -0.588600 & 0.5643 \\
C(3) & 1.521039 & 0.541300 & 2.809973 & 0.0126 \\
C(5) & 1.850277 & 0.787805 & 2.348650 & 0.0320 \\
& 2.890525 & 0.799225 & 3.616660 & 0.0023 \\
\hline \hline R-squared & 0.996818 & Mean dependent var & 66787.69 \\
Adjusted R-squared & 0.996022 & S.D. dependent var & 22176.66 \\
S.E. of regression & 1398.717 & Akaike info criterion & 17.52876 \\
Sum squared resid & 31302555 & Schwarz criterion & 17.77745 \\
Log likelihood & -179.0519 & Hannan-Quinn criter. & 17.58273 \\
F-statistic & 1252.905 & Durbin-Watson stat & 0.896361 \\
Prob(F-statistic) & 0.000000 & & & \\
\hline \hline
\end{tabular}

\section{LITHUANIA}

Dependent Variable: GVA

Method: Least Squares (Gauss-Newton / Marquardt steps)

Date: 03/23/17 Time: 19:02

Sample: 19952015

Included observations: 21

$\mathrm{GVA}=\mathrm{C}(1)+\mathrm{C}(2)^{*} \mathrm{AFF}+\mathrm{C}(3)^{\star} \mid \mathrm{ND}+\mathrm{C}(4)^{*} \mathrm{CON} 01+\mathrm{C}(5)^{*} \mathrm{TRA}$

\begin{tabular}{lrlrr}
\hline \hline & Coefficient & Std. Error & t-Statistic & Prob. \\
\hline \hline C(1) & 2624.619 & 363.6753 & 7.216931 & 0.0000 \\
$\mathrm{C}(2)$ & -2.382124 & 0.625455 & -3.808627 & 0.0015 \\
$\mathrm{C}(3)$ & 1.034402 & 0.287005 & 3.604121 & 0.0024 \\
$\mathrm{C}(4)$ & 1.854762 & 0.155585 & 11.92119 & 0.0000 \\
$\mathrm{C}(5)$ & 2.021511 & 0.191757 & 10.54203 & 0.0000 \\
\hline \hline R-squared & 0.999185 & Mean dependent var & 19366.92 \\
Adjusted R-squared & 0.998981 & S.D. dependent var & 9687.210 \\
S.E. of regression & 309.2078 & Akaike info criterion & 14.51016 \\
Sum squared resid & 1529752. & Schwarz criterion & 14.75886 \\
Log likelihood & -147.3567 & Hannan-Quinn criter. & 14.56413 \\
F-statistic & 4903.569 & Durbin-Watson stat & 1.346381 \\
Prob(F-statistic) & 0.000000 & & \\
\hline \hline
\end{tabular}




\section{ROMANIA}

Dependent Variable: GVA

Method: Least Squares (Gauss-Newton / Marquardt steps)

Date: 03/23/17 Time: 19:04

Sample: 19952015

Included observations: 21

$\mathrm{GVA}=\mathrm{C}(1)+\mathrm{C}(2)^{\star} \mathrm{AFF}+\mathrm{C}(3)^{\star} \mathrm{IND}+\mathrm{C}(4)^{\star} \mathrm{CON} 01+\mathrm{C}(5)^{\star} \mathrm{TRA}$

\begin{tabular}{rrrrr}
\hline \hline & Coefficient & Std. Error & t-Statistic & Prob. \\
\hline \hline $\mathrm{C}(1)$ & -2989.825 & 3146.627 & -0.950168 & 0.3562 \\
$\mathrm{C}(2)$ & 0.061038 & 0.603815 & 0.101088 & 0.9207 \\
$\mathrm{C}(3)$ & 2.420255 & 0.107806 & 22.45004 & 0.0000 \\
$\mathrm{C}(4)$ & -0.003225 & 0.312716 & -0.010312 & 0.9919 \\
$\mathrm{C}(5)$ & 1.842486 & 0.175428 & 10.50280 & 0.0000 \\
\hline \hline
\end{tabular}

\begin{tabular}{lrlr}
\hline R-squared & 0.998113 & Mean dependent var & 77309.51 \\
Adjusted R-squared & 0.997642 & S.D. dependent var & 42212.67 \\
S.E. of regression & 2049.923 & Akaike info criterion & 18.29325 \\
Sum squared resid & 67234955 & Schwarz criterion & 18.54194 \\
Log likelihood & -187.0791 & Hannan-Quinn criter. & 18.34722 \\
F-statistic & 2116.217 & Durbin-Watson stat & 1.472939 \\
Prob(F-statistic) & 0.000000 & & \\
\hline \hline
\end{tabular}

\section{SLOVAKIA}

Dependent Variable: GVA

Method: Least Squares (Gauss-Newton / Marquardt steps)

Date: 03/23/17 Time: 19:06

Sample: 19952015

Included observations: 21

$\mathrm{GVA}=\mathrm{C}(1)+\mathrm{C}(2)^{*} \mathrm{AFF}+\mathrm{C}(3)^{*} \mathrm{ND}+\mathrm{C}(4)^{*} \mathrm{CON} 01+\mathrm{C}(5)^{*} \mathrm{TRA}$

\begin{tabular}{crlll}
\hline \hline & Coefficient & Std. Error & t-Statistic & Prob. \\
\hline \hline $\mathrm{C}(1)$ & -1544.522 & 711.8626 & -2.169691 & 0.0454 \\
$\mathrm{C}(2)$ & 1.754461 & 1.212953 & 1.446437 & 0.1674 \\
$\mathrm{C}(3)$ & 0.358228 & 0.354178 & 1.011433 & 0.3269 \\
$\mathrm{C}(4)$ & 1.133757 & 0.696320 & 1.628213 & 0.1230 \\
$\mathrm{C}(5)$ & 3.578648 & 0.637005 & 5.617931 & 0.0000 \\
\hline \hline R-squared & 0.997953 & Mean dependent var & \multirow{2}{*}{40442.93} \\
Adjusted R-squared & 0.997441 & S.D. dependent var & 21409.33 \\
S.E. of regression & 1083.049 & Akaike info criterion & 17.01720 \\
Sum squared resid & 18767924 & Schwarz criterion & 17.26590 \\
Log likelihood & -173.6807 & Hannan-Quinn criter. & 17.07118 \\
F-statistic & 1949.799 & Durbin-Watson stat & 1.620466 \\
Prob(F-statistic) & 0.000000 & & & \\
\hline \hline
\end{tabular}

Data source: Eurostat, Dataset: National Accounts aggregates by industry (up to NACE A $^{*}$ 4) [nama_10_a64], extracted March 16th, 2017

For Bulgaria, the most important factor in the context of the multiple regression is the Industry (except construction), with a quotient of over 2.39. That is, the increase of the value added in industry with one monetary unit is to produce, over time, a multiplied impact on the GVA. The Constructions and Trade factors have sensible close influences, with their parameters being over 1.62. The least significant impact is corresponding to Agriculture, forestry and fishing, whose regression quotient is below unit. The free term has a very high value, which is also negative, evidence of the other factors, not taken into consideration at the construction of this model, which exert, on the overall, a non-favorable influence on the main indicator's evolution.

The Czech Republic model reveals the significant contribution of the sector Agriculture, forestry and fishing, with a corresponding quotient higher than 5.59. Also, we can appreciate as important the contribution of the Constructions factor, characterized by a regression quotient of over 5 . The Industry (except construction) and Wholesale and retail trade, transport, accommodation and food service activities factors have influences that are situated within the interval $1.14-1.62$. The negative and sizable value of the free term indicates the presence of additional factors whose influence on the GVA is negative. The $R$ squared and Adjusted $R$-Squared tests have values very close to reference 1 , therefore the model is suitable for further analyses and forecasts.
The situation in the case of Estonia is characterized by the presence of the negative influence exerted by the Agriculture, forestry and fishing factor, whose regression quotient is slightly lower than -4.00 . To be noted that all other independent variables have favorable influences, and the free term is positive, even if not so significant, as value, when compared to the quotients of the four factors, denoting the positive influence of the group of potential factors not taken into consideration within this model. The tests associated to the regression model allow us to favorably appreciate its reliability.

In Hungary, the first factor of the model, that is Agriculture, forestry and fishing, has a negative impact on the main indicator, in the context of this model. The Construction is the factor with the most significant positive value, having a regression quotient of over 1.85. The other two factors also exert positive influences, with lower amplitude. The high values of the R-squared and Adjusted R-Squared qualify this model as relevant for the scope of the analysis. Also, the complex of factors not included at this stage, whose impact is revealed by the free term, are favorable, as influences, to the GVA.

The Latvian model is influenced in the highest degree by the Industry (except construction) factor, with a regression quotient higher than 3 . The Constructions' quotient is close by, being higher than 2.74 .

Therefore, we emphasize the combined influence of these two factors. The agriculture is characterized by a 
non-favorable impact, even if the regression quotient has a low value. The Wholesale and retail trade, transport, accommodation and food service activities has a positive influence on the evolution of the main indicator. As expression of other factors that have impact on the GVA, the free quotient is negative. The main tests of the model have high values, close to 1 , so the model is reliable enough.

For Lithuania, the Agriculture, forestry and fishing factor has a negative influence on the overall evolution of the main indicator, with a regression parameter that, in absolute value, is higher than the parameters associated with the other three factors, which have a favorable impact on the main indicator. The free term has a high value and is positive, so there are other independent variables that influence the GVA, in a favorable manner. Also, the R-squared and Adjusted $R$-Squared indicate the quality of the model, which can be used in further studies.

The Romanian regression estimation reveals the major contribution of the industry to the evolution of the GVA, with a quotient over 2.42. The Constructions factor has a minor negative influence. The impact of the Agriculture, forestry and fishing factor is positive, but minor, while the Trade factor is characterized by a quotient over 1.84. The value of the free term is negative and significant, and synthesizes the negative influence of additional factors. The quality of the model is proven by the elevated levels of the R-squared / Adjusted R-Squared tests.
For Slovakia, all factors exert a positive influence on the GVA, while the "hidden" factors are revealed to have a less than favorable impact. The free term is negative and high enough to support this assessment. Trade is the most important influence factor, with a regression quotient of more than 3.57, and then we have the Industry and Constructions. Also, the model is reliable enough, if we observe the high values of the R-squared / Adjusted R-Squared coefficients.

The next step of our analysis is the measure, by similar econometric tools, of the influence of sectorial value added on the GDP. We shall take into consideration the most important factors, for all countries, based on the results discussed in the previous sections. The quick interpretation of basic data reveals that those factors are:

- Industry (except construction) (IND);

- Wholesale and retail trade, transport, accommodation and food service activities (TRA);

- Public administration, defense, education, human health and social work activities (PAD).

The general structure of the regression model is detailed by the following formula:

$$
\mathrm{GDP}=\mathrm{a}_{0}+\mathrm{a}_{1} \cdot \mathrm{IND}+\mathrm{a}_{2} \cdot \mathrm{TRA}+\mathrm{a}_{3} \cdot \mathrm{PAD}
$$

The estimation of the parameters was made according to the least squares method, and the results are presented in Table no. 3.

\section{Table no. 3. Estimation of regression equation - individual country case, influences on GDP}

\begin{tabular}{|c|c|c|c|c|c|c|c|c|c|}
\hline \multirow{2}{*}{\multicolumn{5}{|c|}{$\begin{array}{l}\qquad \text { BULGARIA } \\
\text { Dependent Variable: GDP } \\
\text { Method: Least Squares (Gauss-Newton / Marquardt steps) } \\
\text { Date: } 03 / 23 / 17 \text { Time: } 19: 15 \\
\text { Sample (adjusted): } 19992015 \\
\text { Included observations: } 17 \text { after adjustments } \\
\text { GDP }=C(1)+C(2)^{*} \mid N D+C(3)^{*} T R A+C(4)^{*} P A D\end{array}$}} & \multicolumn{5}{|c|}{ CZECH REPUBLIC } \\
\hline & & & & & $\begin{array}{l}\text { Dependent Variable: } \\
\text { Method: Least Squar } \\
\text { Date: } 03 / 23 / 17 \text { Time } \\
\text { Sample: } 19952015 \\
\text { Included observation } \\
\text { GDP }=C(1)+C(2)^{*} \mid N L\end{array}$ & $\begin{array}{l}\text { Sauss-Newto } \\
17\end{array}$ & $\begin{array}{l}\text { n / Marquardt } \\
\text { PAD }\end{array}$ & teps) & \\
\hline & Coefficient & Std. Error & t-Statistic & Prob. & & Coefficient & Std. Error & t-Statistic & Prob. \\
\hline$C(1)$ & -42.40918 & 1208.340 & -0.035097 & 0.9725 & $C(1)$ & -1623.508 & 1116.951 & -1.453517 & 0.1643 \\
\hline$C(2)$ & 1.709233 & 1.216131 & 1.405467 & 0.1833 & $\mathrm{C}(2)$ & 1.533158 & 0.208688 & 7.346635 & 0.0000 \\
\hline $\mathrm{C}(3)$ & 3.787803 & 1.460577 & 2.593360 & 0.0223 & $C(3)$ & 0.826613 & 0.295584 & 2.796539 & 0.0124 \\
\hline $\mathrm{C}(4)$ & -0.113685 & 1.418607 & -0.080139 & 0.9373 & $C(4)$ & 3.273971 & 0.409366 & 7.997659 & 0.0000 \\
\hline R-squared & 0.988395 & Mean depen & ent var & 29956.49 & R-squared & 0.999338 & Mean depen & ent var & 110895.8 \\
\hline Adjusted R-squared & 0.985717 & S.D. depend & nt var & 11606.17 & Adjusted R-squared & 0.999221 & S.D. depend & nt var & 44882.67 \\
\hline S.E. of regression & 1387.085 & Akaike info $\mathrm{cr}$ & terion & 17.51012 & S.E. of regression & 1252.964 & Akaike info $\mathrm{cr}$ & terion & 17.27405 \\
\hline Sum squared resid & 25012058 & Schwarz crite & & 17.70617 & Sum squared resid & 26688603 & Schwarz crite & ion & 17.47301 \\
\hline Log likelihood & -144.8360 & Hannan-Quir & criter. & 17.52961 & Log likelihood & -177.3776 & Hannan-Quin & n criter. & 17.31723 \\
\hline F-statistic & 369.0635 & Durbin-Wats & & 0.800717 & F-statistic & 8548.725 & Durbin-Wats & in stat & 1.042527 \\
\hline Prob(F-statistic) & 0.000000 & & & & Prob(F-statistic) & 0.000000 & & & \\
\hline
\end{tabular}




\begin{tabular}{|c|c|c|c|c|c|c|c|c|c|}
\hline \multicolumn{5}{|c|}{$\begin{array}{l}\quad \text { ESTONIA } \\
\text { Dependent Variable: GDP } \\
\text { Method: Least Squares (Gauss-Newton / Marquardt steps) } \\
\text { Date: 03/23/17 Time: } 19: 19 \\
\text { Sample: } 19952015 \\
\text { Included observations: } 21 \\
\text { GDP }=\mathrm{C}(1)+\mathrm{C}(2)^{\star} \mathrm{IND}+\mathrm{C}(3)^{\star} \mathrm{TRA}+\mathrm{C}(4)^{\star} \mathrm{PAD}\end{array}$} & \multicolumn{5}{|c|}{$\begin{array}{l}\text { Dependent Variable: GDP } \\
\text { Method: Least Squares (Gauss-Newton / Marquardt steps) } \\
\text { Date: } 03 / 23 / 17 \text { Time: } 19: 20 \\
\text { Sample: } 19952015 \\
\text { Included observations: } 21 \\
\text { GDP }=C(1)+C(2)^{\star} I N D+C(3)^{\star} T R A+C(4)^{\star} P A D\end{array}$} \\
\hline & Coefficient & Std. Error & t-Statistic & Prob. & & Coefficient & Std. Error & t-Statistic & Prob. \\
\hline $\begin{array}{l}C(1) \\
C(2) \\
C(3) \\
C(4) \\
\end{array}$ & $\begin{array}{r}-591.6469 \\
0.291714 \\
3.087714 \\
2.839533\end{array}$ & $\begin{array}{l}110.7345 \\
0.495282 \\
0.348352 \\
0.328829\end{array}$ & $\begin{array}{r}-5.342932 \\
0.588985 \\
8.863779 \\
8.635289 \\
\end{array}$ & $\begin{array}{l}0.0001 \\
0.5636 \\
0.0000 \\
0.0000 \\
\end{array}$ & $\begin{array}{l}C(1) \\
C(2) \\
C(3) \\
C(4)\end{array}$ & $\begin{array}{r}-267.4341 \\
1.767699 \\
2.043693 \\
1.972495\end{array}$ & $\begin{array}{l}1031.329 \\
0.495961 \\
0.762279 \\
0.448393\end{array}$ & $\begin{array}{r}-0.259310 \\
3.564185 \\
2.681029 \\
4.399029\end{array}$ & $\begin{array}{l}0.7985 \\
0.0024 \\
0.0158 \\
0.0004\end{array}$ \\
\hline $\begin{array}{l}\text { R-squared } \\
\text { Adjusted R-squared } \\
\text { S.E. of regression } \\
\text { Sum squared resid } \\
\text { Log likelihood } \\
\text { F-statistic } \\
\text { Prob(F-statistic) }\end{array}$ & $\begin{array}{r}0.998878 \\
0.998680 \\
210.8467 \\
755757.3 \\
-139.9527 \\
5043.760 \\
0.000000\end{array}$ & $\begin{array}{l}\text { Mean depend } \\
\text { S.D. depende } \\
\text { Akaike info cri } \\
\text { Schwarz criter } \\
\text { Hannan-Quin } \\
\text { Durbin-Watso }\end{array}$ & $\begin{array}{l}\text { nt var } \\
\text { it var } \\
\text { erion } \\
\text { on } \\
\text { criter. } \\
\text { itat }\end{array}$ & $\begin{array}{l}11464.88 \\
5802.743 \\
13.70978 \\
13.90874 \\
13.75296 \\
1.055767\end{array}$ & $\begin{array}{l}\text { R-squared } \\
\text { Adjusted R-squared } \\
\text { S.E. of regression } \\
\text { Sum squared resid } \\
\text { Log likelihood } \\
\text { F-statistic } \\
\text { Prob(F-statistic) }\end{array}$ & $\begin{array}{r}0.997931 \\
0.997566 \\
1299.422 \\
28704471 \\
-178.1421 \\
2733.515 \\
0.000000\end{array}$ & $\begin{array}{l}\text { Mean depenc } \\
\text { S.D. depende } \\
\text { Akaike info cr } \\
\text { Schwarz crite } \\
\text { Hannan-Quin } \\
\text { Durbin-Wats }\end{array}$ & $\begin{array}{l}\text { ent var } \\
\text { nt var } \\
\text { terion } \\
\text { ion } \\
\text { n criter. } \\
\text { in stat }\end{array}$ & $\begin{array}{l}78294.67 \\
26339.43 \\
17.34687 \\
17.54583 \\
17.39005 \\
0.727268\end{array}$ \\
\hline \multicolumn{5}{|c|}{$\begin{array}{l}\text { Dependent Variable: GDP } \\
\text { Method: Least Squares (Gauss-Newton / Marquardt steps) } \\
\text { Date: } 03 / 23 / 17 \text { Time: } 19: 21 \\
\text { Sample: } 19952015 \\
\text { Included observations: } 21 \\
\text { GDP }=\mathrm{C}(1)+C(2)^{\star} \mid N D+C(3)^{\star} T R A+C(4)^{\star} P A D\end{array}$} & \multicolumn{5}{|c|}{$\begin{array}{l}\text { Dependent Variable: GDP } \\
\text { Method: Least Squares (Gauss-Newton / Marquardt steps) } \\
\text { Date: } 03 / 23 / 17 \text { Time: } 19: 23 \\
\text { Sample: } 19952015 \\
\text { Included observations: } 21 \\
\text { GDP }=C(1)+C(2)^{\star} I N D+C(3)^{\star} T R A+C(4)^{\star} P A D\end{array}$} \\
\hline & Coefficient & Std. Error & t-Statistic & Prob. & & Coefficient & Std. Error & t-Statistic & Prob. \\
\hline $\begin{array}{l}C(1) \\
C(2) \\
C(3) \\
C(4)\end{array}$ & $\begin{array}{r}-873.7654 \\
1.473139 \\
1.325432 \\
3.656430\end{array}$ & $\begin{array}{l}398.3269 \\
0.662737 \\
0.566184 \\
0.854875\end{array}$ & $\begin{array}{r}-2.193589 \\
2.222812 \\
2.340993 \\
4.277149\end{array}$ & $\begin{array}{l}0.0425 \\
0.0401 \\
0.0317 \\
0.0005\end{array}$ & $\begin{array}{l}C(1) \\
C(2) \\
C(3) \\
C(4)\end{array}$ & $\begin{array}{r}-48.54487 \\
1.647497 \\
1.086172 \\
2.725856\end{array}$ & $\begin{array}{l}812.2901 \\
0.763324 \\
0.628080 \\
0.757893\end{array}$ & $\begin{array}{r}-0.059763 \\
2.158320 \\
1.729352 \\
3.596625\end{array}$ & $\begin{array}{l}0.9530 \\
0.0455 \\
0.1019 \\
0.0022\end{array}$ \\
\hline $\begin{array}{l}\text { R-squared } \\
\text { Adjusted R-squared } \\
\text { S.E. of regression } \\
\text { Sum squared resid } \\
\text { Log likelihood } \\
\text { F-statistic } \\
\text { Prob(F-statistic) }\end{array}$ & $\begin{array}{r}0.993309 \\
0.992128 \\
641.6138 \\
6998361 \\
-163.3227 \\
841.2581 \\
0.000000\end{array}$ & $\begin{array}{l}\text { Mean depen } \\
\text { S.D. depend } \\
\text { Akaike info c } \\
\text { Schwarz crite } \\
\text { Hannan-Qui } \\
\text { Durbin-Wats }\end{array}$ & $\begin{array}{l}\text { dent var } \\
\text { ent var } \\
\text { iterion } \\
\text { rion } \\
\text { in criter. } \\
\text { on stat }\end{array}$ & $\begin{array}{l}14570.15 \\
7231.723 \\
15.93549 \\
16.13445 \\
15.97867 \\
1.486304\end{array}$ & $\begin{array}{l}\text { R-squared } \\
\text { Adjusted R-squared } \\
\text { S.E. of regression } \\
\text { Sum squared resid } \\
\text { Log likelihood } \\
\text { F-statistic } \\
\text { Prob(F-statistic) }\end{array}$ & $\begin{array}{r}0.994609 \\
0.993657 \\
850.2576 \\
12289947 \\
-169.2353 \\
1045.376 \\
0.000000\end{array}$ & $\begin{array}{l}\text { Mean depen } \\
\text { S.D. depend } \\
\text { Akaike info C } \\
\text { Schwarz crite } \\
\text { Hannan-Qui } \\
\text { Durbin-Wats }\end{array}$ & $\begin{array}{l}\text { dent var } \\
\text { ent var } \\
\text { iterion } \\
\text { rion } \\
\text { in criter. } \\
\text { on stat }\end{array}$ & $\begin{array}{l}21550.06 \\
10675.94 \\
16.49860 \\
16.69756 \\
16.54178 \\
0.914908\end{array}$ \\
\hline $\begin{array}{l}\text { Dependent Variable: } \\
\text { Method: Least Square } \\
\text { Date: 03/23/17 Time } \\
\text { Sample: } 19952015 \\
\text { Included observations } \\
\text { GDP }=C(1)+C(2)^{\star} \text { IND }\end{array}$ & $\begin{array}{l}\text { RON } \\
\text { OP } \\
\text { (Gauss-Newtc } \\
9: 24 \\
21 \\
C(3)^{*} T R A+C(4\end{array}$ & ton / Marquardt & teps) & & $\begin{array}{l}\text { Dependent Variable: } \\
\text { Method: Least Square } \\
\text { Date: 03/23/17 Time } \\
\text { Sample: } 19952015 \\
\text { Included observations } \\
\text { GDP }=C(1)+C(2)^{*} \text { IND }\end{array}$ & $\begin{array}{l}\text { SLO } \\
\text { Gauss-Newto } \\
26 \\
(3)^{*} \mathrm{TRA}+\mathrm{C}(4\end{array}$ & $\begin{array}{l}\text { JAKIA } \\
\text { n / Marquardt s } \\
\text { ) } \mathrm{PAD}\end{array}$ & teps) & \\
\hline & Coefficient & Std. Error & t-Statistic & Prob. & & Coefficient & Std. Error & t-Statistic & Prob. \\
\hline $\begin{array}{l}C(1) \\
C(2) \\
C(3) \\
C(4)\end{array}$ & $\begin{array}{r}-2920.436 \\
2.496890 \\
1.803209 \\
1.007817\end{array}$ & $\begin{array}{l}1357.982 \\
0.197004 \\
0.205977 \\
0.588639\end{array}$ & $\begin{array}{r}-2.150570 \\
12.67431 \\
8.754423 \\
1.712114\end{array}$ & $\begin{array}{l}0.0462 \\
0.0000 \\
0.0000 \\
0.1051\end{array}$ & $\begin{array}{l}\mathrm{C}(1) \\
\mathrm{C}(2) \\
\mathrm{C}(3) \\
\mathrm{C}(4)\end{array}$ & $\begin{array}{r}-1837.734 \\
1.089920 \\
2.182835 \\
2.696115\end{array}$ & $\begin{array}{l}302.3971 \\
0.214402 \\
0.459158 \\
0.415311\end{array}$ & $\begin{array}{r}-6.077219 \\
5.083545 \\
4.753995 \\
6.491802\end{array}$ & $\begin{array}{l}0.0000 \\
0.0001 \\
0.0002 \\
0.0000\end{array}$ \\
\hline $\begin{array}{l}\text { R-squared } \\
\text { Adjusted R-squared } \\
\text { S.E. of regression } \\
\text { Sum squared resid } \\
\text { Log likelihood } \\
\text { F-statistic } \\
\text { Prob(F-statistic) }\end{array}$ & $\begin{array}{r}0.998429 \\
0.998152 \\
2073.781 \\
73109679 \\
-187.9587 \\
3601.825 \\
0.000000\end{array}$ & $\begin{array}{l}\text { Mean depen } \\
\text { S.D. depend } \\
\text { Akaike info cr } \\
\text { Schwarz crite } \\
\text { Hannan-Quir } \\
\text { Durbin-Wats }\end{array}$ & $\begin{array}{l}\text { lent var } \\
\text { nt var } \\
\text { iterion } \\
\text { rion } \\
\text { n criter. } \\
\text { on stat }\end{array}$ & $\begin{array}{l}86922.34 \\
48240.44 \\
18.28178 \\
18.48073 \\
18.32496 \\
1.715103\end{array}$ & $\begin{array}{l}\text { R-squared } \\
\text { Adjusted R-squared } \\
\text { S.E. of regression } \\
\text { Sum squared resid } \\
\text { Log likelihood } \\
\text { F-statistic } \\
\text { Prob(F-statistic) }\end{array}$ & $\begin{array}{r}0.999441 \\
0.999342 \\
603.4163 \\
6189891 \\
-162.0337 \\
10124.18 \\
0.000000\end{array}$ & $\begin{array}{l}\text { Mean depeno } \\
\text { S.D. depende } \\
\text { Akaike info cr } \\
\text { Schwarz crite } \\
\text { Hannan-Quin } \\
\text { Durbin-Watso }\end{array}$ & $\begin{array}{l}\text { ent var } \\
\text { nt var } \\
\text { terion } \\
\text { ion } \\
\text { n criter. } \\
\text { n stat }\end{array}$ & $\begin{array}{l}44738.20 \\
23521.46 \\
15.81274 \\
16.01169 \\
15.85591 \\
1.296307\end{array}$ \\
\hline
\end{tabular}

Data source: Eurostat, Datasets: National Accounts aggregates by industry (up to NACE A*64) [nama_10_a64], GDP and main components (output, expenditure and income) [nama_10_gdp], extracted March 16th, 2017 
The interpretation of the regression estimations emphasizes the following situations:

In Bulgaria, the value added corresponding to Wholesale and retail trade, transport, accommodation and food service activities has the most significant influence on the GDP. An increase by one euro of this independent variable shall lead to an increase of the main indicator by more than 3.78 euro. The Industry (except construction)also presents a favorable influence, its regression quotient is 1.70 . The only factor whose impact is negative is Public administration, defense, education, human health and social work activities, however the quotient has a small value when compared to the previous two (-0.11). The free term is negative and much higher than the regression quotients, therefore we conclude that there are other factors with a non-favorable impact on the GDP of Bulgaria.

In the case of the Czech Republic, we outline the major influence of the factor Public administration, defense, education, human health and social work activities, which is characterized by a coefficient of more than 3.27. Next in the hierarchy, we have the Industry (except construction), whose growth by one unit will induce an increase by 1.53 of the main indicator and the least sizable influence corresponds to Wholesale and retail trade, transport, accommodation and food service activities, having a quotient of 0.82 . All factors have therefore a favorable influence on the GDP, and there is to be noted the position of the industrial-related sector, which is a pillar of sustainable development of this country. The value of the free term is negative and very high (considered as absolute level).

Estonia's economy is characterized by the high and positive influence of the Wholesale and retail trade, transport, accommodation and food service activities factor, which has a coefficient higher than 3.08 , the other two factors also have positive regression quotients. While the Industry (except construction) is associated with a lower coefficient, that is 0.38 , the Public administration, defense, education, human health and social work activities factor shall generate an increase of the GDP by more than 2.83 units, in the case in which its own value would grow by one unit. The free term is negative, and also has a significant value, over 591 in absolute value.

The regression coefficients estimated for the Hungarian model show relatively similar influences for the three factors considered, and all these influences are positive. That is, the first place in the hierarchy is held by Wholesale and retail trade, transport, accommodation and food service activities factor, its coefficient being 2.04, then we have Public administration, defense, education, human health and social work activities (1.97) and, on the last position, Industry (except construction), with a coefficient of 1.76 . The value of the free term is negative and some 100 times higher than the most prominent regression quotient of the model.

In Latvia, the regression model outlines the prominence of Public administration, defense, education, human health and social work activities, whose favorable influence was measured with a regression quotient of 3.65. The second factor in the hierarchy is the Industry (except construction), whose coefficient is 1.47 and the Wholesale and retail trade, transport, accommodation and food service activities trails on the third place with a close value, of 1.32. Also in this case, there is a sizable and negative influence of additional factors, proven by the major value of the free term.

For Lithuania, the GDP has the Public administration, defense, education, human health and social work activities as the most important factor, in the scope of our analysis. It's regression coefficient is 2.72 . The Industry (except construction) has a less sizable influence, with a coefficient of 1.64 , while the weakest factor is the Wholesale and retail trade, transport, accommodation and food service activities (1.64). The free term is negative, but smaller in size when compared to the other countries' cases.

The model estimated for Romania reveals the positive and prominent impact of Industry (except construction), a factor with a regression coefficient of 2.49. The other two independent variables have quotients below 2 , that is 1.80 for the factor Wholesale and retail trade, transport, accommodation and food service activities and 1.00 for Public administration, defense, education, human health and social work activities. The high level of the industrial factor's coefficient offers reliable incentive for measures aimed towards the further development of this group of sector within the Romanian economy. The model is characterized by a significant, negative, free term.

In the case of Slovakia, the most important factor is Public administration, defense, education, human health and social work activities, as its coefficient has a value of 2.69. Next, we have Wholesale and retail trade, 
transport, accommodation and food service activities, while the weakest impact is associated with Industry (except construction), with regression coefficients of 2.18 and 1.08 , respectively. To be observed, the negative and significant value of the free term.

All models presented have significant values of the tests $R$-Squared and Adjusted R-Squared, the smallest value within the panel being however above 0,98 . We, thus, take into account the fact that the models are well founded and indicate significant links between independent variables and the GDP.

\section{Ponclusions}

While Industry (except construction) and Wholesale and retail trade, transport, accommodation and food service activities are the most significant influence factors for all economies analyzed, the trade has the highest impact on the three former soviet Baltic countries. The sector with the least major contribution is the Arts, entertainment and recreation etc., for all economies. All regression models are characterized by high values of $R$-Squared, over $99 \%$, which allows us to consider that the models are reliable and can be applied in further analyses. In some cases, the free parameter has negative values, while in other cases is positive.

Regarding the impact of the selected factors on the GDP, they act in a different manner at the level of countries analyzed. We observe that the independent factor Industry (except construction) has the strongest influence in Romania, the GDP in the case of the other countries is mainly influenced by on of the other two factors.

The author assumes to further study the sectorial evolution for this panel of countries, by applying multiple regression-based models to other groups of factors and, as more data becomes available, by extending the datasets subjected to analysis.

\section{REFERENCES}

1. Anghelache, C., Mitruț, C. and Voineagu, V. (2013), Statistică macroeconomică. Sistemul Conturilor Naționale, Economica, București.

2. Astafieva, E. (2014), Factors of change in the value added of the industrial sector in 2013, Russian Economic Developments, vol. 3, pp. 42-44.

3. Bălănescu, M. (2013), Importance of small and medium-sized enterprises in Romanian economy, Annals of the "Constatin Brâncuşi”" University of Târgu Jiu, Economy Series, no. 4, pp. 205-212.

4. Iachimov, N. (2013), Information sources for regional analysis: necessity, availability, flaws and recommendations, Economy and sociology: Theoretical and Scientifical Journal, no. 3, pp. 180-185.

5. Lehmann, R. and Wohlrabe, K. (2013), Sectoral gross value-added forecasts at the regional level: Is there any information gain?, University Library of Munich, Germany in its series MPRA Paper with number 46765.

6. Melihovs, A. and Kasjanovs, I. (2011), The Convergence Processes in Europe and Latvia, Latvijas Banka in its series Discussion Papers with number 2011/01.
7. Motofei, C. (2017), Vectors of economic growth in the Eastern area of the EU, Theoretical and Applied Economics, vol. XXIV, no. 1(610 Spring), pp. 215-226.

8. Pawlas, I. (2015), The Visegrad Countries and European Union membership - selected issues, 18th International Academic Conference, 25 August 2015, London, United Kingdom.

9. Păunică, M., Ştefănescu, A., Calu, D.A., Nicolae, F. and Țurlea, E. (2009), Performanța şi auditul intern - 0 abordare duală în entitățile sectorului administrației publice locale, Studia Universitatis Vasile Goldiş, Arad-Seria Ştiințe Economice, vol. 1, no. 1, pp. 216-226.

10. Piroi, M. and Păunica, M. (2015), How Technology can Help in Reducing Romania's Budget Deficit, Proceedings of The 15th European Conference on eGovernment, ECEG 2015, University of Portsmouth (p. 419).

11. Stoykova-Kanalieva, A. (2010), Opportunities for analytical comparison in the national economies of Bulgaria and Romania, Analele Ştiintifice ale Universitătii „Alexandru loan Cuza” din laşi, no. 57 (November), pp. 465-482.

12. www.eurostat.eu 